DEATH GAMES AND THE PERSISTENCE OF MEMORY: J. G. BALLARD'S WORLD WAR II FICTIONS

\author{
Pedro Groppo ${ }^{1 \times}$
}

${ }^{1}$ Universidade Federal da Paraíba, João Pessoa, PB, Brasil

\begin{abstract}
This article is a discussion of J. G. Ballard's (semi-)autobiographical war narratives, with a focus on the different textual strategies and processes of signification Ballard employs from his avant-garde novel The Atrocity Exhibition (1970) to the feverish fictional account of his time in World War II China in "The Dead Time" (1977) and Empire of the Sun (1984) to his more reflective autobiographical texts The Kindness of Women (1990) and Miracles of Life (2008). Ballard's obsessive repetition of many of the same images attests to the problematics of representation of the traumatic event, and ultimately represents a complex and rich work of fabulation that escapes categorizations of fiction and autobiography.

Keywords: war fiction; trauma; autobiography; psychoanalysis.
\end{abstract}

" $\mathrm{PhD}$ in Literary Theory and Comparative Literature from Federal University of Minas Gerais, and teaches English at Federal University of Paraíba. E-mail: pgroppo@gmail.com. ORCID: https://orcid.org/0000-00016801-4503. 
The work of J. G. Ballard (1930-2009) has always been about the aftermath of World War II in some way or another. In his monograph on David Cronenberg's film adaptation of Crash (2001), the English writer Iain Sinclair $(2003,34)$ suggests that that avant-garde novel is far more autobiographical than the nominal, fictionalized account of Ballard's childhood in wartime Shanghai, Empire of the Sun (1984). Sinclair is right in claiming that Empire has overtly autobiographical elements and that it could be read as part of a tradition of fictionalized war memoirs, such as Jerzy Kosinski's The Painted Bird. Crash (2001), on the other hand, is a scandalous work of imaginative fiction that prompted a reviewer for Jonathan Cape to pronounce the author "beyond psychiatric help" (46). The protagonists of both novels have slightly fictionalized versions of J. G. (James Graham) Ballard's own name (James Ballard in Crash, Jim Graham in Empire), and join a host of characters that, during the span of fifty-two years, have borne glaring similarities with their author.

Empire is a coming-of-age story about a boy sent to a POW camp during the Japanese occupation of China in World War II. Following the novel's publication in 1984, the cryptic symbols and images from Ballard's fiction find an ur-text; the empty swimming pools and obsessively repetitive images could now be explained by this new work. Angela Carter (2012), in her review of Empire, was skeptical, and rightly claimed that the "entire context of the novel is true, but Jim's adventures are invention. The book is by no means autobiographical" $(2012,108)$.

Despite the seductiveness of reading Empire and the other war narratives as keys to decode Ballard's other work, one should be wary of such an operation. As Roger Luckhurst (1997) argues, critics who advocate such a reading

detach the "autobiographies" in order to give them the textual sanction to operate as decoding machines for the oeuvre. And yet Empire and [The Kindness of Women] slip the fixity of the division that would render transparent the fictional code because they are, of course, autobiographical novels... The fictionalising goes much further than the alteration of a few facts: Kindness often contradicts, rewrites, and even erases sections of Empire. No simple identity, either, can be established between J. G. Ballard and the Jamie/Jim figure in the texts.... What the initial reviewers believed they had found in these texts-the key to unlock the opacity of the fictions-already founders over the indeterminate zone between fiction and autobiography that Empire and Kindness occupy. (162)

Moreover, in 2008, Ballard published his de facto autobiography, Miracles of Life, and that it reads largely like a Ballard novel should be further indication that Ballard constantly blurs the line between reality and fiction. Miracles repeats many events fictionalized in Empire and The Kindness of Women under the guise of autobiography, but Ballard could be simply striving for some sort of artistic consistency, or even that acts of remembrance only have meaning when interspersed with fiction.

Pierre Janet (1925), a French psychiatrist contemporary with Freud, argued for psychological health being dependent on an individual's ability to narrativize temporal experience: 
Memory, like belief, like all psychological phenomena, is an action; essentially, it is the action of telling a story. ... The teller must not only know how to [narrate the event], but must also know how to associate the happening with the other events of his life, how to put it in its place in that life-history which each one of us is perpetually building up and which for each one of us is an essential element of his personality. (661-62)

This describes Ballard's project, especially in Kindness, in which the memories of World War II comprise only the first part of the novel, which actually covers much of the protagonist's life, with further chapters having significant parallels to his fiction. For instance, The Crystal World comes to mind when Jim experiments with LSD; elements of Crash are interspersed with his infamous "Crashed Cars" exhibition in 1970, and an episode that essentially rewrites the short story "My Dream of Flying to Wake Island". At times, Miracles appears to be a concurrent, parallel narrative of Kindness, a straightforward recollection fleshed out with memories, rather than a factual skeleton fleshed out with fiction-as it seems the case with Kindness. Ballard (2012) spoke of that novel as being "substantially fiction," a retelling of his "life seen through the mirror of the fiction prompted by that life" (345).

One of Freud's discoveries, as reported in the "Wolf-Man" case history, is that analysis is a process of construction, not authentic recollections of remote events. "These scenes from infancy," Freud (1996) wrote,

are not reproduced during the treatment as recollections, but are the products of construction. ... Previously unconscious recollections ... may be [true]; but they are often distorted from the truth, and interspersed with imaginary elements. (208)

This is analogous to the way memory and imagination work in the writing of fiction. Ballard's background, a story closely resembling Empire, was publicized at the time, and the literary establishment was all too eager to pigeonhole and explain him away. Empire, to be fair, has strong autobiographical elements, but it is not a novel that departs stylistically from Ballard's other work, nor was it the first autobiographical piece written by him. No one really believed that Crash was autobiographical, even if the protagonist shared Ballard's name; “The Dead Time," a story published in 1977, was thematically very close to Empire, but it also shared some of its delirious and surrealistic images. Empire represented a departure for Ballard only in the sense that it could fit into a genre that was not science fiction or fantastic fiction: it can be read as a war novel, and it meant that the establishment could finally see him as a mainstream writer.

In this article, I will explore how Ballard conflates public and private trauma in Empire and other texts with clear allusions to his wartime background. I do not attempt, however, to posit any claims that the texts are autobiographical, only that if they are read in context with Ballard's fictional and non-fictional oeuvre, they may form a rich and complex picture, albeit inconsistent-and for that very reason all the more interesting. 


\section{The Atrocity Exhibition}

The Atrocity Exhibition (1990) and "The Terminal Beach" (1964) are parts of a particular project carried by Ballard in the late 1960s and early 1970s to come to terms with the nature of the media landscape and the death of affect, a period that coincided with the aftermath of the death of his wife, Mary. I believe Sinclair has a valid point by arguing the autobiographical inclinations of Crash, reinforced by Ballard's use of autobiographical allusions, so far as it plays a key role in Ballard's fictional development of his own biography. Atrocity is one of Ballard's most complex texts, sometimes characterized as a collection of interrelated short stories or condensed novels, or even a collage or a narrative woven out of found texts that attempt a reinterpretation of reality in terms of the reconfiguration of central elements in order to evoke an inversion of the inner and outer world. Andrzej Gasiorek (2005) describes it as a text that works by way of "suggestions, resonances, echoes" (59), almost an index of Ballardian icons, themes, and concerns. The text is so dense, in Luckhurst's (2012) assessment, that it "will take decades to decompress Ballard's brutal paragraphs, to trace out the wiring diagram of this fiendishly booby-trapped device" (35).

If we assume that there is an overarching narrative to Atrocity, even though that narrative is represented obliquely, we can attempt to sketch some idea of the events that take place in the novel. The central character (whom I will call Traven), haunted by his wartime experiences and by the death of his wife, is on a quest for meaning. The war for him had become, as Ballard (1990) writes,

an expression of the failure of his psyche to accept the fact of its own consciousness, and of his revolt against the present continuum of time and space. ... [H] is intention is to start World War III, though not, of course, in the usual sense of the term. The blitzkriegs will be fought out on the spinal battlefields, in terms of the postures we assume, of our traumas mimetized in the angle of a wall or balcony. (6)

Traven believes that by enacting certain bizarre experiments, they will reconfigure the relation between self and world, embodying a sort of "secularized apocalyptic ur-Christ figure who seeks to redeem the world" (Gasiorek 60). Vaughan, Ballard's most famous Christ (or Satanic) figure from Crash, who dies in a collision with Elizabeth Taylor's limousine, makes his debut in Atrocity; to redeem themselves and others, these Christ-like figures need to reconfigure and reinterpret the world according to their own needs, and what is truly Satanic about them is that they make it look as if it is the world that must be rewritten after them. The strength of much of Ballard's fiction stems from this powerful and seducing way of looking at the world. Crash is his most radical and impressive experiment in a double play that simultaneously repels and attracts the reader.

Naming the protagonist of Crash James Ballard approximates the reader, by establishing a pact of honesty, even if illusory. Ballard does away with an alter ego: the Ballard in the book is the same as the Ballard who wrote it, or so it seems. 
The fragmented narratives of The Atrocity Exhibition have the opposite effect on the reader, implying a distanced and intellectualized attitude: Ballard enacts a breakdown of identity and narrative, with a protagonist that seemed to change identity from one chapter to another (Traven/Talbot/Trallis/Trabert/Travis/Talbert/ Travers), at the same time a lecturer and a patient at a psychiatric institution, a bomber pilot, and an avatar for Christ's reincarnated body. There is a rejection of conventional reader identification as vague plots for the individual stories emerge only with careful reading, characters die and reappear in different roles, and events follow an irrational logic. Crash, for its part, attempts to apply some of the unorthodox, deviant logics exposed in the previous book inside a linear narrative.

The first overtly autobiographical aspects in Ballard's fiction appear in the jumble of lists that populate Atrocity. All mentions of Shanghai in Atrocity are inside lists, a nod to the Surrealist technique of automatic writing. In his annotations to the novel, Ballard encourages a reading of those lists as being produced without conscious filtering (90). Some of the images described seem to be strongly autobiographical in content due to their similarities to his posterior, more nominally autobiographical, works. In the chapter titled "The Atrocity Exhibition", Travis listens to a series of transmissions on his pirate radio, one of which is described as "V.J.-Day, the bodies of Japanese troops in the paddy fields at night. The next day, as he walked back to Shanghai, the peasants were planting rice among the swaying legs" (5). In "The University of Death," there is a second mention of Shanghai, one of a number of "journeys to an interior": "montage landscapes of war-webbing heaped in pits beside the Shanghai-Nanking railway; bargirls' cabins built out of tyres and fuel drums; dead Japanese stacked like firewood in L. C. T.s off Woosung pier" (27). In "The Great American Nude," this is one of the "landscapes of the dream" that "preoccupied Talbert": "The melancholy back of the Yangtse, a boom of sunken freighters off the Shanghai Bund. As a child he rowed out to the rusting ships, waded through saloons awash with water. Through the portholes, a regatta of corpses sailed past Woosung Pier" (82). Without knowledge of Ballard's subsequent work, these seem to blend into the myriad references of the complex puzzle that is the narrative of Atrocity. The idea of trauma is already present, however, in the figure of the protagonist, a bomber pilot with no true fixed identity (his name shifts from Trabert to Talbot to Travis, etc.). Ballard's protagonists are always wounded, obsessive characters, but here and in "The Terminal Beach," he locates the source of this malaise for the first time in World War II.

In the commentary added to recent editions of the book, Ballard advises readers "daunted by the unfamiliar narrative structure" to "turn the pages until a paragraph catches your eye. If the images or ideas seem interesting, scan the nearby paragraphs for anything that resonates in an intriguing way. ... In effect, you will be reading the book in the way it was written" (vi). While his recommendation does elucidate the formal logic of the novel-with no fixed entry point-it might be disingenuous to forego other aspects of that logic that only become apparent if one approaches it in a linear fashion. "Tolerances of the 
Human Face," the longest chapter of the novel, stands out by breaking a pattern: the language is unusually direct, unadorned, with a sense of urgency lacking in other parts of the novel. It functions as a piece of frank, "straight" recollection in the midst of all the supposedly free-association and automatic writing that defines Atrocity. This section, titled "Too Bad," was also the first to be composed, dating from the 1950s. The section narrates an American atrocity committed against a shipload of Japanese prisoners awaiting repatriation, which Travers supposedly witnessed. In the previous section, "Cinecity," Travers is watching atrocity films when the following sentence segues into the memory of "Too Bad": "Watching from the embankment, Travers found himself thinking of the eager deaths of his childhood" (112). It could be a straightforward analepsis, inserted into the surrealistic collage of Atrocity, but its apparent normality destabilizes the text: to which reality does this section refer?

In Atrocity, the protagonist, who has been through some trauma-in one story we learn that he was dead for two minutes, in another he was a bomber pilot, yet in another he lost his wife-is desperately trying to reinvest the empty world of the media landscape with some kind of affect. As Luckhurst (1997) summarizes, the protagonist of Atrocity is "searching for a 'modulus', a measure, a mode of explanation, that would both re-fix his name and identity as well as serve to decode the densely overdetermined landscapes in which he appears" (86). He plans to do so by reenacting violent media-saturated events such as the assassination of John F. Kennedy. As Dr. Nathan, the character in charge of this simulacral "course of treatment", a demented form of weird psychoanalysis, explains: "You can see he's trying to build bridges between things-this Kennedy business, for example. $\mathrm{He}$ wants to kill Kennedy again, but in a way that makes sense" (Ballard 6).

In the first eight chapters of Atrocity the central character experiences these shifts in identity, but in "You and Me and the Continuum," Traven becomes a Christ-like figure, his body already starting to become unmoored like his identity. Here he is described as an "unidentified Air Force pilot" whose "mortal remains" were to be found in unexpected places (abstract and concrete). In this chapter, we still have the familiar figures of Dr. Nathan, Karen Novotny, and Catherine Austin and a fragmentary narrative. The paragraph headings are now organized alphabetically, suggesting some kind of (outside) order being imposed. The chapter ends with the sentence "As his own identity faded, its last fragments glimmered across the darkening landscape, lost integers in a hundred computer codes, sand-grains on a thousand beaches, fillings in a million mouths" (138), which finds an echo in the closing lines of Crash (2001): "The aircraft rise from the runways of the airport, carrying the remnants of Vaughan's semen to the instrument panels and radiator grilles of a thousand crashing cars, the leg stances of a million passengers" (224). Traven becomes enmeshed in the virtual world of the media landscape, an abstract code, invisible and atomized. Traven becomes part of the simulacra, part of a world without time, without affect, and more importantly, without pain. Trauma becomes then the driving force for this act of resignification and transformation. 
The subsequent chapters of Atrocity have no characters, and are even more experimental. For one, character names appear only briefly in the paragraph headings, and in chapter 12, the first three headings read, "Each afternoon in the deserted cinema"; "Tallis was increasingly distressed"; "by the images of colliding motor cars" (153-56). The headings in the first seven chapters, in contrast, have a more indexical purpose, with cryptic titles such as "Marriage of Freud and Euclid" and "Biomorphic Horror." They are alphabetized in "You and Me and the Continuum" and the remainder follow this pattern of a concurrent or parallel narrative in which Traven continues to exist, but not in the actual body of the text, as if his dissolution shifted his presence to another level, a shift represented textually. Therefore, to read Atrocity randomly, as Ballard proposes, would be to miss this important formal logic at work, one that goes largely unnoticed in most discussions of the book.

Ballard's pronouncements about his own fiction can be a little disingenuous, belying the careful construction of his texts. By presenting himself as a writer who rarely reads or talks about literature-going as far as denying having read Joseph Conrad before writing The Drowned World, an assertion so unlikely it could even be interpreted as pure mischievousness-Ballard cements his persona as a romantic, but he chooses his predecessors with the same care he labors over his texts. Paul Crosthwaite (2009) elaborates on this notion, discussing passages from Atrocity:

[E]ven if we understand these passages as constituting acts of autobiographical revelation, they might equally be read as conscious, perhaps even (as the novel's title implies), "exhibitionist," displays of extreme authorial experience, and their fragmentary sentences as skillful, performative evocations of post- traumatic testimony. (97)

We have to remember that there was nothing overtly autobiographical in Atrocity, since Ballard at the time had never alluded to his wartime experiences. Therefore, it is only with hindsight that we approach texts such as Atrocity looking for autobiographical elements. It is clear on the text of "Tolerances of the Human Face" that the trauma is Traven's, and in the context of the novel, it is astute to treat those passages as playing a performative role, expressing trauma, repetition, and abreaction.

\section{"The Dead Time"}

The unnamed protagonist of "The Dead Time" (1982) is a twenty-year old inmate of a Japanese camp outside Shanghai during the final weeks of the war. Taking place after the bombing of Hiroshima and Nagasaki, and during the "dead time" before peace, the protagonist and a colleague are to be released as long as they deliver the bodies to the cemetery in a couple of trucks. ${ }^{1}$

Stretched out on the frayed grass were some fifty corpses, laid out in neat rows as if arranged with great care and devotion. All were fully dressed and lay with their 
feet towards us, arms at their sides, and I could see from the bright pallor on their faces that these people, whoever they were, had only recently died. (147)

Ballard associates this period with the death of affect, an emotional distancing clearly necessary to carry the task through, a "kind of forced intimacy that absolved [the protagonist] from all future contact or obligation" (150). After the corpses are loaded onto the truck, the narrator notices how much better fed they were than he and any of his inmates, as well as the complete absence of signs of violence. Within the nightmarish logic of the story, the corpses probably belong to some other time, to the time before the war, to a time in which taking them to a cemetery would make some sense.

"The Dead Time" is very much about an interstitial space in time between realities: when do these corpses cease to be human beings and become objects? When one of the trucks fails, some of the corpses are dumped into a body of water. Later on, they find the corpses clogging up a passage, and the protagonist is surprised to recognize each of them; he is taken over by a "presentiment of death-though not [his] own or of these drowned creatures" (154). As the bodies are retrieved and handled even more, he sees for the first time a "distinct personality" in the face of one of them, a woman, "visualizing her talking" to him. The more the bodies are handled, the harder it gets to relate to them as mere objects, a rather paradoxical view since their appearance worsens with time. In fact, the protagonist starts to see it as a mission, and guards the completeness of his truck's bodies calling it his "flock" and removing the ones mistakenly taken from his companion's truck, seen as "intruders, ... members of a rival clan" (157). The story is one of Ballard's illustrations of his theme of investing death and dead objects with meaning, in which the repetition of the same thing does not divest it from affect: quite the opposite. Meaning is changed and displaced, and the matter for the protagonist is now one of security, "loyalty," and "the feeling that they, the dead, were more living than the living who had deserted [him]" (158). He feels he is "the instrument of the new order ... delegated by [the dead] to bring to the world," and soon the whole planet would "share in the new life they had earned for us" (161). As in Empire, death provides a spiritual form of nourishing. Ballard touches here on the reality of a world on the brink of the irreconcilable recognition of the prospect of total self-annihilation, in the case of the atom bomb. The story allows for a mental distortion that effaces subjectivity, and like death and the bomb itself, brings about "total fusion and non-differentiation of all matter", to quote Atrocity (48). Following the Freudian concept of the death drive-the aim of all life is death - this lack of subjectivity would be the ultimate relief, a resolution to this uncertain and unstable "dead time."

Carrying a famished Chinese girl in his arms, the protagonist, without thinking, gives her a morsel of his own flesh for her to eat. Instead of letting her die on her own, he leads her, with a Eucharist of his own body, into his flock, harnessing the power of the dead to move into a mental domain that transcends death: "At last, through this child and my body, the dead were coming to life, rising from their fields and doorways and coming to greet me ... I had given my 
death to them and so brought them into this world" (168). The motif of the rising of the dead is repeated in Ballard's fictions of the late 1960s and 1970s: in Crash, when the protagonist finally engages in a sex act with Vaughan, he describes a post-orgasmic feeling in bizarre terms: "In our wounds we celebrated the re-birth of the traffic-slain dead, the deaths and injuries of those we had seen dying by the roadside and the imaginary wounds of the millions yet to die" (203), which recalls the "millions of mouths" of "Tolerances of the Human Face." One of the most horrific images in "The Terminal Beach" is that of a pool of test-mannequins that turn into corpses, echoed in the ending of High-Rise (2011), where a swimming pool becomes a "bone-pit" covered with "skulls, bones and dismembered limbs of dozens of corpses," a "crowded beach visited by a sudden holocaust" (170). In "The Dead Time," we witness the rising of the dead as the protagonist arrives at the Soochow camp where his parents are supposed to be, finally reunited with their dead bodies. Only in this final embracing of death is he able to say, "I knew now that the war was over" (163).

\section{Empire of the Sun}

Empire of the Sun, even with its overtly autobiographical elements, does not signal a transition into realism for Ballard. The novel can be just as subjective and hallucinatory as sections of Atrocity in parts, and in the first chapter, we already have a blurring of the boundaries between self and world. Empire takes place in the same inner space as all of Ballard's novels, a phenomenological domain where the inner world of the mind and the outer world of reality meet and fuse. This interstitial zone does not commit to either exterior or interior space; it is an imaginative fusion of both. It is not wholly psychological since the outer world appears equally informed by the individual's desires, and there is a constant slippage of one realm into the other. On the first pages of Empire (1984), Ballard tells us how the novel is supposed to be read, as a blend of reality in fiction not unlike Atrocity:

Jim had begun to dream of wars. At night the same silent films seemed to flicker against the wall of his bedroom in Amherst Avenue, and transformed his sleeping mind into a deserted newsreel theatre. During the winter of 1941 everyone in Shanghai was showing war films. Fragments of his dreams followed Jim around the city; in the foyers of department stores and hotels the images of Dunkirk and Tobruk, Barbarossa and the Rape of Nanking sprang loose from his crowded head. ... The whole of Shanghai was turning into a newsreel leaking from inside his head. $(11,14)$

Jim's consumption of images and icons from movies, magazines, posters and ads is, as David Punter (1985) notes, a consumption of "implanted icons" and "discarded images," the true "points of reference against which our action takes place" (10). Subjectivity is produced by these representations, and as Tamas Benyei (2000) argues, inner space is the end of intimacy as pure interiority as this 
reality is neither the external or the internal world, but a composite, a symptomatic product in which "there is a circulation of signifiers ... traversing subjectivity as well, producing it and being produced by it" (255). This complicates the notion of trying to identify what is real in these semi-autobiographical fictions. In this sense, the war in Empire is already filtered through media representations, wartime Shanghai reimagined as the post-1960s media landscape.

Jim's relation to media echoes Traven's, to the point that he wonders whether his brain "had been damaged by too many war films" (14): "In an eerie way, these shuffled images of tanks and dive-bombers were completely silent, as if his sleeping mind was trying to separate the real war from the make-believe conflicts invented by Pathé and British Movietone." His dreams are like the films of atrocity projected by Dr. Nathan and Traven; the lack of sound signifying at the same time a detachment from reality but also a mythical quality, recalling the otherworldly quality of the Zapruder film, the eighteen seconds of silent film that captured the Kennedy assassination. There is already a concern in trying to separate reality from fiction, as Ballard elaborates:

Jim had no doubt which was real. The real war was everything he had seen for himself since the Japanese invasion of China in 1937, the old battlegrounds at Hunjao and Lunghua where the bones of the unburied dead rose to the surface of the paddy fields each spring. Real war was the thousands of Chinese refugees dying of cholera in the sealed stockades at Pootung, and the bloody heads of communist soldiers mounted on pikes along the Bund. In a real war no one knew which side he was on, and there were no flags or commentators or winners. In a real war there were no enemies. (14)

Ironically, "real war" for Jim is quite the opposite of what we would expect: a Gothic scenario of "unburied dead" rising to the surface or with heads on spikes. Either Jim knows something about the reality of war that a child like him could not have known-that it is unspeakably violent, cruel, chaotic, and indifferent-or these Gothic excesses are a fancy of his overactive imagination. As the novel unfolds, these two views will converge. We see here an example of a double discourse that is present in Empire, a voice that alternates between the innocence of its young protagonist and the hindsight of the implied, more mature author, in a kind of Bakhtinian double-voiced discourse. It is from this device that, as Gasiorek suggests, Empire derives much of its humor (145), as Jim often misunderstands what is going on around him.

Yet the presence of the mature voice of the implied author creates a gap, and it allows Ballard to do much more than just humor, though. Consider, for instance, the scene in which Jim returns to his house in Shanghai after being separated from his parents. Expecting to find them there, he is greeted by an empty house and signs of an altercation. There are two descriptions of Jim looking at footprints. The first reads: 
His mother's clothes were scattered across the unmade bed, and open suitcases lay on the floor. Someone had swept her hairbrushes and scent bottles from the dressing-table, and talcum covered the polished parquet. There were dozens of footprints in the powder, his mother's bare feet whirling within the clear images of heavy boots, like the patterns of complicated dances set out in his parents' foxtrot and tango manuals. (Ballard 62)

The second:

In the talcum on the floor around him he could see the imprints of his mother's feet. She had moved from side to side, propelled by an over-eager partner, perhaps one of the Japanese officers to whom she was teaching the tango. Jim tried out the dance steps himself, which seemed far more violent than any tango he had ever seen, and managed to fall and cut his hand on the broken mirror. (64)

These two passages occur within two pages of each other, and three days seem to have passed between one impression and the other. In the first, Jim's impression is subtle, making the connection between the footprints and patterns of dances he had seen in books; whereas in the second, Jim imagines his mother might have been teaching the tango to an officer, an impression only a child could make. It is impossible to identify, however, where one voice ends and the other begins; they are doubled and juxtaposed. Jim never grasps the brutal, hard reality-that his mother was violently seized by the Japanese-even though the reader is keen enough to realize it. This gap allows for humor, but more importantly, it gives Ballard a visible rationale, a fictional inscription of a double voice that was already in place in his work. Ballard's protagonists often act like Jim, with a child-like curiosity and eagerness to pursue their own obsessions with total disregard for others and even their own well-being. Part of the uneasiness of reading Crash or Atrocity is precisely because this double discourse is so veiled: the voice of the critical distance never takes over-there is no safety net. In Empire, it is precisely because of the more overt double discourse that we can read it as a matrix of Ballardian concerns and icons, as it is always indexing Ballard's work in its context. The drained swimming-pools, the suspension of moral values, the obsession with airplanes, just to name a few, are described with the fascination of a young teenager but with the voice and the vocabulary that belongs to the Ballard of The Drowned World and The Atrocity Exhibition.

Jim's predicament is one of cognitive mapping, an attempt to find some way of orientating himself within a situation he is not equipped to understand. As Gasiorek suggests, "Jim's apprehension of events is stronger than his producible vocabulary and [the text] describes him struggling to discover a vocabulary adequate to his experiences" (157). These experiences make him grow old too fast and Jim realizes that morality might get in the way of survival, causing him to fail to recognize himself, as this key passage illustrates:

A strange doubling of reality had taken place, as if everything that had happened to him since the war was occurring within a mirror. It was his mirror 
self who felt faint and hungry, and who thought about food all the time. He no longer felt sorry for this other self. Jim guessed that this was how the Chinese managed to survive. Yet one day the Chinese might emerge from the mirror. (Ballard 102)

This notion of "doubling of reality" here is about Jim's character, but it can also be read as central to the understanding of Ballard's fiction, a work that oscillates between one thing and the other: reality and fiction, the outside and the inside, the manifest and the latent content, and between Shanghai and Shepperton. The double discourse is another example of the presence of a double, a presence that is ethereal and haunting. More importantly, the doubling of the image, especially through films, thoroughly characterizes Ballard's explorations of his past. As we have seen in Atrocity, the section "Too Bad" appears as if conjured by the images projected on a screen, and part of the "treatment" in the novel is to reconfigure, reenact, and reinvest images with a meaning. In Empire, the reality of war exists first in the form of images, as if leaking from Jim's mind to be concretized in real life. Earlier in the novel, when Jim finds footprints in his mother's bedroom, he is unable to understand what has happened, and finally stares at his image in the mirror:

Jim sat on the bed, facing the star-like image of himself that radiated from the centre of the mirror. A heavy object had been driven into the fulllength glass, and pieces of himself seemed to fly across the room, scattered through the empty house. He fell asleep at the foot of his mother's bed, rested by the scent of her silk nightdress, below this jewelled icon of a small exploding boy. (62)

Ballard's logic is visual: for Jim, the trauma of being separated from his parents and thrown into the war is one that shatters his reality, scattering "pieces of himself" across the room, a similar effect to that of Atrocity, in which Traven's identity is splintered. Not only his identity, but in Atrocity's formal collage, also gone are notions of linearity, coherence, and unity; the subject is divided and never reconstituted again. William Burroughs' analogy of Atrocity as a bomb is strikingly apt to describe its disorienting effects, as it explodes and shatters everything that is inside, and it is up to the reader to (try to) reassemble the pieces.

In the first quotation in the previous paragraph, Jim likens himself to the Chinese, an interesting parallel, since earlier he states, "The Chinese enjoyed the spectacle of death, Jim had decided, as a way of reminding themselves of how precariously they were alive. They liked to be cruel for the same reason, to remind themselves of the vanity of thinking that the world was anything else" (57). We can trace a development of the death of affect from these impressions of the Chinese. Jim's fear of course, is that one day he might become a figure that enjoys the spectacle of death. Later on, the notion that life was "worth nothing" (words that echo Jim's American friends Frank and Basie's first impressions of him) begins to take hold as he observes the death of American pilots during raids to the camp: 
Jim grieved for these American pilots, who died in a tangle of their harnesses, within sight of a Japanese corporal with a Mauser and a single English boy hidden on the balcony of this ruined building. Yet their end reminded Jim of his own, about which he had thought in a clandestine way ever since his arrival at Lunghua. He welcomed the air raids, the noise of the Mustangs as they swept over the camp, the smell of oil and cordite, the deaths of the pilots, and even the likelihood of his own death. Despite everything, he knew he was worth nothing. He twisted his Latin primer, trembling with a secret hunger that the war would so eagerly satisfy. (248)

This is the first time that Jim is all-too-eager to give in to his "destructive element" and let death embrace him in the search for his obsessions, and to end as so many Ballardian characters do. The death of affect here is a question of survival and adaptability. For Ballard, this adaptability is only apparent-this fascination with death is something that must be fought if one expects to survive. Can it even be called adaptability, or is it just a matter of the lure, of seduction? As in "The Dead Time," the protagonist is seduced by "a logic more powerful than reason" but is able to save himself.

\section{The Kindness of Women and Miracles of Life}

In Kindness (1991), Ballard returns to this moment of "dead time" (corresponding to Part III of Empire), after the end of the war but before the Japanese surrender. In the 1991 novel, the guards at Lunghua disappear: "By leaving the camp I had stepped outside my own head. Had the atom bombs in some way split the sky and reversed the direction of everything?" (46). Jim decides to walk the eight miles back to Shanghai in order to join his family. Unlike Empire, this Jim has a composed distance from the events and there is none of the hallucinatory energy that characterized the former novel. On a railway station, he sees four Japanese soldiers, fully armed, waiting. One of them signals to Jim as he walks by, beckoning him to come closer. Jim is surprised to find out that one of the soldiers is holding a telephone wire, coiled around the neck of a young Chinese man. The Chinese is out of place, "unlike the soldiers and myself" (55), he states. Ballard compresses this interstitial "dead time" into this tense scene in which time is stretched: Jim is paralyzed, unable to leave, even though he wants to explain that the war is over he does not know enough of the language. "From the moment I left Lunghua all the clocks had stopped. Time had suspended itself, and only the faraway drone of an American aircraft reminded me of a world on the other side of the pearly light" (55). One of the soldiers decides to inspect Jim's belt, testing the plastic between his hands, and finally destroying it as the Chinese is finally killed. "None of them had been touched by the youth's death, as if they knew that they too were dead and were matter-of-factly preparing themselves for whatever end would arrive out of the afternoon sun" (56). As in "The Dead Time", imagining that one's self and the whole world are dead is a way of justifying the death of affect so as to cope with the close contact of the reality of death. 
For the first time it seemed obvious that this remote country platform was the depot from which all of the dead of the war had been dispatched to the creeks and burial mounds of Lunghua. The four Japanese soldiers were preparing us for our journey. I and the Chinese whom they last suffocated were their last arrivals, and when we had gone they would close the station and set out themselves. (Kindness 56)

Upon returning to Shanghai, Jim struggles to resume his old life, as if "landed in an unfamiliar future", relating in traumatic terms, "so much had happened that I had not been able to remember or forget" (60), and he feels his sense of self changed, as if he had "mislaid part of [his] mind somewhere between Lunghua and Shanghai" (60). He admits being disappointed he did not stay behind with the Japanese, as if, in a way, he wanted the security they could have provided him in their ushering toward death.

In Kindness, Ballard plays the game the critics accused him of playing and puts his wartime experiences at the center of his work, and the death of this Chinese peasant as a primal scene. Jim's "entire world had been shaped by the camp," and "instead of wanting to escape from it", he had sought "to burrow ever more deeply into its heart" (48) and in a sense the main theme of Kindness is Jim's failure to work through personal trauma and the difficulty of living in an unresolved psychological limbo. Another character confronts him: "A part of it actually happened to you. All those car crashes and pornographic movies, Kennedy's death, they're your way of turning it into a film, something violent and glamorous" (270). This identification is such that Jim's mind is "up there, molded against the screen" (269). Gasiorek argues that by rendering it safe and displacing the violence to the realm of the imaginary, he ends up by "colonizing" his psyche to the glamorized allure the violence subsequently represents (150). The episode of the railway station is repeated in Miracles, in which Ballard writes of the moment of uncertainty: "August 1945 formed a strange interregnum when we were never wholly certain that the war had ended, a sensation that stayed with me for months and even years" (103). Walking toward the railway station, he is aware of a singsong sound (absent in Kindness), which turns out to be the Chinese on his knees, being strangled by Japanese soldiers. One of the soldiers calls Jim up and asks to see his transparent plastic belt, "a prized novelty that no Japanese was likely to have seen" (107), and examines it slowly, while Jim waits, and the Chinese is choked to death. There is a clear disconnect between the atrocity taking place and the matter-of-fact manner of the Japanese, who demand him to act in the same way. They were, Ballard writes, "beyond the point where life and death meant anything at all. ... Peace, I realized, was more threatening because the rules that sustained war, however evil, were suspended. The empty paddy fields and derelict villages confirmed that nothing mattered" (108). Ballard continues describing the in-between world where wars merged into one another, and the proximity of his autobiography to his fictional narratives calls into question how much of Miracles are actually memories, unadorned and uninformed by decades of filtering these memories through his imagination. 
Miracles, written after Ballard was diagnosed with cancer in the late 2000s, is in many ways his testament, in which he details how he wanted to be remembered. For the first time in his written output, he talks candidly about his children (the "miracles of life" of the title), trying to reconcile his personal life and his work-in which the only children are projections of himself. In his autobiography, Ballard finally concedes that his formative wartime experiences were what populated his imagination from the very beginning: "For a long time I resisted this, but I accept now that it is almost certainly true. The memories of Shanghai that I had tried to repress had been knocking at the floorboards under my feet, and had slipped quietly into my fiction" (120).

The repetitions of certain elements throughout Ballard's work, even though they have been read (following Ballard himself) as a working through, seem more akin to repetition compulsion, acquiring pathos and potency in their relentlessness. They repeat, but their traumatic components never subside, only to displace onto other elements. Jeanette Baxter (2012) contends that Ballard's "authorial doubles" in his non-fiction are often at odds with each other, and discrepancies between their accounts should be taken as a sign that "these autobiographical 'nonfictions' [should be set] apart from claims to veracity" (61). In 1991, following the publication of Kindness, Ballard returned to Shanghai for the first time after the war, accompanied by a BBC crew to make the documentary Shanghai Jim. Ballard recounts the experience in "Unlocking the Past" (1996):

One can never go home, the American novelist Thomas Wolfe has written, meaning that everything changes, the past and one's memories of it. Since coming to England in the grey, austere days after the war, I had kept alive my precocious memories of Shanghai. ... But what if my memories were false? My great fear was that far from evoking new memories, the visit might erase the old ones that had sustained me for so many years. (173)

The memories from Shanghai, the unresolved trauma of those years, were what fueled Ballard's imagination, and the fear Ballard alludes here is of losing not only cherished memories, but also the psychic support they provided him, and the very structure that formed his identity as a writer. In 1987, Empire was turned into a Hollywood production, directed by Steven Spielberg and written by Tom Stoppard. Coincidentally, some of the film was actually shot in Shepperton Studios, located near Ballard's home just outside London. Ballard can be seen briefly in the background in one of the scenes as a party guest, even though the scene in which he supposedly interacted with his young alter ego (played by Christian Bale) was cut from the final film. This uncanny encounter with these doubles-of himself, his childhood home, his parents-taking part of a fantasy he wrote, is fictionalized in the last chapter of Kindness, titled "Dream's Ransom." There is a telling moment in which the director asks Jim to come up with a line of dialogue for his cameo: "I stared at [the director], too tongue-tied to even say my name. [...] I felt myself drifting into a trance, trying to imagine this line of dialogue missing from my earlier life, which I had spent my entire career trying to define" 
(331). Interestingly, Jim's reaction is one of shock, and he cannot say his name, even though he was not asked for it. Not coming up with those words is analogous to not saying one's name, as it is an operation of protecting one's identity.

That Ballard essayed a resolution of these operations in Kindness, before his actual return to China, should be enough indication of their status as fabulation, as part of the myth he created for himself.

The film had served a deeper role for me-seeing its masterly recreation of Shanghai had been the last act in a profound catharsis that had taken decades to draw to a close. All the powers of modern film had come together for this therapeutic exercise. The puzzle had solved itself: the mirror ... had been broken from within. In my mind the image had fused with the original, enfolding it within its protective wings. Looking at the great hotels along the Bund, unchanged after fifty years, I could almost believe that my memories of Shanghai had always been a film, endlessly played inside my head during my years in England after the war. (341)

To believe in the fantasy constructed by Kindness, that of a working through, of a cathartic experience that somehow resolves itself, is to believe a novelistic device. The greatest weakness of Kindness as a novel is this simple-mindedness, an eagerness to resolve and to achieve a cure. In Miracles, Ballard seems to have succumbed to the relief this fiction brings, and his work's rich ambiguity becomes overdetermined and impoverished as a "therapeutic exercise." As we know from Shanghai Jim and "Unlocking the Past," however, the puzzle did not and could not solve itself. In Miracles, the return to Shanghai is the "psychological equivalent of an adventure holiday. I had walked up to a mirage, acceptant that in its way it was real, and then walked straight through it to the other side" (273). There is little of the complex repetition and unsettling media replication of Atrocity and Crash here, but Ballard returns to the notion that his memories had always been a film: that Ballard himself started believing his own fiction to some degree is a testament to the power of the imagination to reconstitute and mythologize, never reaching an end.

We should take heed of Angela Carter's astute reading of Empire, in which she claims there is nothing autobiographical about it, and continue reading Ballard as a fantasist. His project of reimagining his life in the context of his work in Kindness makes it clear that there is no stable ground that we can claim as truthful or autobiographical. In this sense, a text such as Crash can even be more autobiographical than Miracles, and it is probably more so because in Crash we have Ballard at his most naked, without the distance that (even reinvented) memories and history can provide.

Ballard's weaving of traumatic memories become detached from their historical or personal source and are reconstituted as imaginative signifiers. In this respect, Ballard is very much in line with other postmodernist authors looking back at the atrocities of the $20^{\text {th }}$ century. For Fredric Jameson (1991), the superficiality and loss of historicity of postmodernism—or late capitalism—is 
linked to this process of deferred action, a "retroactivity" in which "people become aware of the dynamics of some new system, in which they are themselves seized, only later on and gradually" (xix). The apparent depthlessness of these cultural artifacts might be read, as Paul Crosthwaite observes, "as serving simultaneously to ward off and to register a range of insistent, unresolved historical traumas" (23). Indeed, reverberations of World War II are indeed "machinations of capitalist reification", but also a sign of "psychic defense-formation" (23). Angela Carter may call Ballard a fantasist, but it becomes clear that from this perspective, Ballard's fantasies are very much culturally and historically determined, taking part in a wider cultural process of deferred action.

\section{Note}

1. The story has the same hallucinatory quality as Part III of Empire, and the rather incredible plot was probably inspired by Henri-Georges Clouzot's 1953 film The Wages of Fear. In it, four inexperienced drivers are hired to transport in two trucks a load of nitroglycerine to extinguish the fire on an oil well, a job considered too dangerous for their syndicated employees.

\section{Works cited}

Ballard, J. G. Crash. Picador, 2001.

Ballard, J. G. Empire of the Sun. Gollancz, 1984.

Ballard, J. G. "Empire of the Surreal: Interview with Nicholas Zurbrugg". Extreme Metaphors: Selected Interviews with J.G. Ballard, 1967-2008. Organized by Simon Sellars and Dan O’Hara, Fourth Estate, 2012, pp. 340-349.

Ballard, J. G. High-Rise. Liveright, 2011.

Ballard, J. G. "Introduction". Crash. Picador, 2001.

Ballard, J. G. Miracles of Life: Shanghai to Shepperton: An Autobiography. Harper, 2008.

Ballard, J. G. The Atrocity Exhibition. RE/Search Publications, 1990.

Ballard, J. G. The Kindness of Women. Farrar, 1991.

Ballard, J. G. “The Dead Time”. Myths of the Near Future. Cape, 1982, pp. 144-163.

Ballard, J. G. "The Terminal Beach". The Complete Stories of J. G. Ballard. Norton, 2010, pp. 589-604.

Ballard, J. G. "Unlocking the Past". A User's Guide to the Millennium. Picador, 1996, pp. 173-177.

Baxter, Jeannette. "Uncanny Forms: Reading Ballard's Non-Fiction." J.G. Ballard Visions and Revisions. Edited by Jeannette Baxter and Rowland Wymer, Palgrave Macmillan, 2012, pp. 50-68.

Benyei, Tamas. "White Light: J. G. Ballard's Empire of the Sun as a War Story." The Anachronist, 2000, pp. 249-75.

Carter, Angela. “J.G. Ballard: Empire of the Sun". Expletives Deleted: Selected Writings. Vintage, 2012, pp. 104-118.

Crosthwaite, Paul. Trauma, Postmodernism, and the Aftermath of World War II. Palgrave Macmillan, 2009. 
Freud, Sigmund. Three Case Histories. Edited by Philip Rieff. Translated by James Strachey, Simon \& Schuster, 1996.

Gasiorek, Andrzej. J.G. Ballard. Manchester UP, 2005.

Jameson, Fredric. Postmodernism, Or, The Cultural Logic of Late Capitalism. Durham: Duke UP, 1991.

Janet, Pierre. Psychological Healing: A Historical and Clinical Study. Allen \& Unwin, 1925.

Luckhurst, Roger. "Ballard/Atrocity/Conner/Exhibition/Assemblage." J.G. Ballard Visions and Revisions, by Jeannette Baxter and Rowland Wymer, Palgrave Macmillan, 2012, pp. 35-49.

Luckhurst, Roger. The Angle between Two Walls: The Fiction of J.G. Ballard. St. Martin's, 1997.

Punter, David. The Hidden Script: Writing and the Unconscious. Routledge, 1985.

Sinclair, Iain. Crash. BFI, 2003.

Recebido em: 04/04/2020

Aceito em: 15/06/2020 